\title{
Characterizing the Retinal Phenotype in the High-Fat Diet and Western Diet Mouse Models of Prediabetes
}

\author{
Bright Asare-Bediako ${ }^{1}$, Sunil K. Noothi ${ }^{2}$, Sergio Li Calzi ${ }^{2}$, Baskaran Athmanathan ${ }^{3}$, \\ Cristiano P. Vieira ${ }^{2}$, Yvonne Adu-Agyeiwaah ${ }^{1}$, Mariana Dupont ${ }^{1}$, Bryce A. Jones ${ }^{4}{ }^{3}$, \\ Xiaoxin X. Wang ${ }^{5}$, Dibyendu Chakraborty ${ }^{2}$, Moshe Levi ${ }^{5}$ (D) Prabhakara R. Nagareddy ${ }^{3}$ (D) \\ and Maria B. Grant ${ }^{2, *}$ \\ 1 Vision Science Graduate Program, School of Optometry, University of Alabama at Birmingham, \\ Birmingham, AL 35233, USA; basareb@uab.edu (B.A.-B.); yvonnad@uab.edu (Y.A.-A.); \\ mdupont@uab.edu (M.D.) \\ 2 Department of Ophthalmology and Visual Sciences, School of Medicine, The University of Alabama \\ at Birmingham, Birmingham, AL 35294, USA; sunilnooti@uabmc.edu (S.K.N.); scalzi@uabmc.edu (S.L.C.); \\ cvieira@uabmc.edu (C.P.V.); dchakraborty@uabmc.edu (D.C.) \\ 3 Division of Cardiac Surgery, Department of Surgery, Ohio State University Wexner Medical Center, \\ Columbus, OH 43210, USA; baskaran.athmanathan@osumc.edu (B.A.); \\ prabhakara.nagareddy@osumc.edu (P.R.N.) \\ 4 Department of Pharmacology and Physiology, Georgetown University, Washington, DC 20057, USA; \\ baj46@georgetown.edu \\ 5 Department of Biochemistry and Molecular \& Cellular Biology, Georgetown University, \\ Washington, DC 20057, USA; xiaoxin.wang@georgetown.edu (X.X.W.); moshe.levi@georgetown.edu (M.L.) \\ * Correspondence: mariagrant@uabmc.edu
}

Received: 9 January 2020; Accepted: 13 February 2020; Published: 18 February 2020

\begin{abstract}
We sought to delineate the retinal features associated with the high-fat diet (HFD) mouse, a widely used model of obesity. C57BL/6 mice were fed either a high-fat ( $60 \%$ fat; HFD) or low-fat ( $10 \%$ fat; LFD) diet for up to 12 months. The effect of HFD on body weight and insulin resistance were measured. The retina was assessed by electroretinogram (ERG), fundus photography, permeability studies, and trypsin digests for enumeration of acellular capillaries. The HFD cohort experienced hypercholesterolemia when compared to the LFD cohort, but not hyperglycemia. HFD mice developed a higher body weight $(60.33 \mathrm{~g}$ vs. $30.17 \mathrm{~g}, p<0.0001)$ as well as a reduced insulin sensitivity index (9.418 vs. 62.01, $p=0.0002$ ) compared to LFD controls. At 6 months, retinal functional testing demonstrated a reduction in a-wave and b-wave amplitudes. At 12 months, mice on HFD showed evidence of increased retinal nerve infarcts and vascular leakage, reduced vascular density, but no increase in number of acellular capillaries compared to LFD mice. In conclusion, the HFD mouse is a useful model for examining the effect of prediabetes and hypercholesterolemia on the retina. The HFD-induced changes appear to occur slower than those observed in type 2 diabetes (T2D) models but are consistent with other retinopathy models, showing neural damage prior to vascular changes.
\end{abstract}

Keywords: retinal phenotype; neural infarcts; vascular leakage

\section{Introduction}

Diabetes is now considered a worldwide epidemic [1,2]. Recent reports indicate that over $90 \%$ of diabetic individuals have type 2 diabetes (T2D) [3,4]. The most common microvascular complication of diabetes is diabetic retinopathy (DR) [2]. Despite a growing number of different approaches to arrest $\mathrm{DR}$, the incidence and prevalence of DR continues to rise [5]. The understanding of the pathogenesis of DR remains incomplete [4], and this is, in part, due to the lack of readily available models that 
completely recapitulate the metabolic phenotype [6]. The high-fat diet (HFD) mouse model has been described as a robust model for investigating obesity-associated T2D and its related metabolic complications [7]. Studies have shown that HFD-fed mice develop obesity, impaired glucose tolerance, and reduced insulin sensitivity [8,9] with systemic manifestations involving adipose tissue [10], liver [8], and kidneys [11]. However, the ocular changes associated with the HFD model have not been fully investigated. Moreover, the typical Western diet (WD; 40\% fat) has also been given to rodents to recapitulate obesity-driven pathology. However, to mimic the features of T2D, the administration of low-dose Streptozotocin (STZ) is also given to the WD mice [12-14].

The retinal response to high fat exposure would likely involve local changes in the expression of lipid transport proteins, such as the liver X receptors (LXRs). The LXRs are the key transcription factors that regulate lipid and cholesterol metabolism [15]. While liver $X$ receptor alpha (LXR $\alpha)$ is expressed only in some tissues, the expression of liver $X$ receptor beta (LXR $\beta$ ) is ubiquitous [12]. Previously we showed that whole body $L X R \alpha / \beta$ deficiency resulted in the generation of increased numbers of acellular capillaries, while LXR agonists improved DR in Streptozotocin (STZ)-induced diabetes [12] and in diabetic Lepr ${ }^{\mathrm{db} / \mathrm{db}}(\mathrm{db} / \mathrm{db})$ mice [16]; however, it is not known if the WD modulates the expression of LXR in the retina.

Retinopathy is typically characterized by macroglia activation and gliosis identified by glial fibrillary acidic protein (GFAP) overexpression, which can be considered as a marker for retinal damage $[17,18]$. In the healthy mammalian retina, GFAP is expressed only in astrocytes and not in Muller cells. Following inherited or acquired retinal pathology, GFAP is expressed also in Muller cells $[19,20]$. GFAP expression in Muller cells has been widely used as a cellular marker for retinal pathology [21-25]. Hypoxia-inducible factor 1 alpha (HIF- $1 \alpha$ ) is known to be a key regulator of a tissue's response to hypoxia [26] and plays a role in obesity-induced metabolic syndrome. It has been shown that HFD leads to gradual increase in HIF- $1 \alpha$ and associated pathological changes in the liver $[27,28]$. However, the role of HIF- $1 \alpha$ in the retina of WD-fed mice is not known.

A better understanding of DR in obesity-driven models is needed and may facilitate the optimal choice of disease models for future investigations. Thus, in the present study, we hypothesized that HFD and WD feeding would result in a distinct retinal phenotype and a time course slower than that observed in models of T2D, such as the $\mathrm{db} / \mathrm{db}$ mouse [29] or the high fructose and high fat fed mouse [30]. For this purpose, we characterized not only systemic endpoints of glucose and lipid metabolism but also the function of the retina and development of retinal pathology, including retinal vascular changes and changes in expression of the critical proteins LXR $\beta, H I F-1 \alpha$, and GFAP.

\section{Materials and Methods}

\subsection{Animals}

All animal experiments were approved by the University of Alabama at Birmingham (IACUC-20467, approved on 06/16/2016) and Georgetown University (animal project \#2017-0059, approved on 10/27/2017), and followed the Association for Research in Vision and Ophthalmology Statement for the Use of Animals. Six to eight-week-old C57BL/6J mice were fed either a low-fat diet (LFD) (10\%kcal fat, 70\%kcal carbohydrate, $20 \%$ protein), a Western diet ( $40 \% \mathrm{kcal}$ fat, $43 \% \mathrm{kcal}$ carbohydrate, $17 \% \mathrm{kcal}$ protein), or a HFD (60\% kcal fat, $20 \% \mathrm{kcal}$ carbohydrate, $20 \% \mathrm{kcal}$ protein) for up to 12 months. Diets were purchased from Research Diets, Inc, New Brunswick, NJ, USA. Full details of the composition of each diet is given in Supplementary Table S1.

\subsection{Body Composition, Glucose Tolerance, and Insulin Sensitivity Testing}

The fat mass, lean mass, and water content of the animals were measured by magnetic resonance imaging using EchoMRI (Echo Medical Systems, LLC, Houston, TX, USA). For glucose and insulin tolerance tests, mice were fasted for 5-6 h, injected intraperitoneally with D-glucose at $1.5 \mathrm{~g} / \mathrm{kg}$ of lean mass and tail bled for glucose and insulin measurements. Blood glucose and insulin levels were 
measured $0,15,30,45,60$, and 120 min after glucose administration. The insulin sensitivity index (ISI) was estimated using the Matsuda-Defronzo method [31].

\subsection{Electroretinogram (ERG)}

ERGs were performed using a LKC Bigshot ERG system. Briefly, mice were dark-adapted overnight. The animals were anesthetized with ketamine $(80 \mathrm{mg} / \mathrm{kg}$ total body mass) and xylazine $(15 \mathrm{mg} / \mathrm{kg}$ total body mass), then dilated with atropine/phenylephrine under dim red light. Once dilated, animals were exposed to 5 full-field white light flashes at 0.25 and $2.5 \mathrm{~cd} . \mathrm{s} / \mathrm{m}^{2}$ under scotopic conditions. The animals were then light-adapted for $5 \mathrm{~min}$ and exposed to 10-15 full-field white light flashes at 10 and $25 \mathrm{~cd} . \mathrm{s} / \mathrm{m}^{2}$ under photopic conditions. Responses were averaged and analyzed using the LKC EM software.

\subsection{Fundus Photography and Fluorescein Angiography}

Fundus photography and fluorescein angiography were performed using the Phoenix Micron IV retinal imaging microscope (Phoenix Technology Group, Pleasanton, CA, USA). Briefly, mice were anesthetized with ketamine and xylazine, then dilated with atropine/phenlylephrine, as described above. Once dilated, the animals were placed on the instrument and fundus photographs were taken. Animals were then given intraperitoneal injection of fluorescein (AK-FLUOR 10\%, Sigma Pharmaceuticals, North Liberty, IA, USA) and the retinal vasculature was imaged with blue light illumination after 5-8 min when all the vessels were filled.

\subsection{Acellular Capillaries Quantification}

Trypsin digestion of the retina was performed according to a previously published protocol [32,33]. Briefly, eyeballs were enucleated and incubated in $4 \%$ paraformaldehyde overnight. Retinas were isolated, washed, and digested in elastase solution (40 Units elastase $/ \mathrm{mL}$; Sigma-Aldrich, St. Louis, $\mathrm{MO}, \mathrm{USA}$ ) to remove the non-vascular tissue. The vascular beds were mounted on glass slides followed by staining with periodic acid-Schiff's base and hematoxylin. About 5-6 fields from the central to mid-periphery were imaged and the number of acellular capillaries per square millimeter were quantified.

\subsection{Immunohistochemistry}

Immunohistochemical staining of mouse retinas was performed according to a previously published protocol [34]. Briefly, mice were euthanized and eyes were immediately enucleated and fixed in $4 \%$ paraformaldehyde (PFA) solution for $15 \mathrm{~min}$. Cornea and lenses were carefully removed and posterior cups were incubated in 15\% sucrose solution in phosphate-buffered saline (PBS) overnight at $4{ }^{\circ} \mathrm{C}$ after washing briefly in PBS. Posterior cups were transferred to $30 \%$ sucrose in PBS for $3-4 \mathrm{~h}$, then embedded in optimal cutting temperature (O.C.T) medium and immediately frozen on dry ice. The frozen samples were stored at $-80^{\circ} \mathrm{C}$ until further processing. The sections were thawed at room temperature for $4 \mathrm{~h}$, washed in PBS for $5 \mathrm{~min}$, and permeabilized with $0.25 \%$ Triton-X in PBS for $5 \mathrm{~min}$ at room temperature. Sections were blocked with $10 \%$ horse serum in $1 \%$ bovine serum albumin (BSA) for $2 \mathrm{~h}$ then incubated with primary antibody diluted in blocking solution (1:100 dilution) overnight at $4{ }^{\circ} \mathrm{C}$. The antibodies used were rabbit anti-GFAP (Abcam, MA, USA), mouse mAB HIF- $1 \alpha$ antibody (Novus Biologicals, CO, USA), LXR- $\beta$ polyclonal antibody (Invitrogen, IL, USA), rabbit anti-Vimentin (Cell Signaling Technology, MA, USA), and isolectin GS-IB4 Alexa Fluor 568 (Life Technologies, OR, USA). Sections were then washed and incubated in fluorescent-labeled secondary antibodies (goat anti-rabbit IgG Alexa Fluor 488, Life Technologies, OR, USA) for $1 \mathrm{~h}$ at room temperature, followed by washing and incubation with 4',6-diamidino-2-phenylindole, dihydrochloride (DAPI) solution (Life Technologies, OR, USA) for $5 \mathrm{~min}$ at room temperature. Finally, sections were washed and mounted with anti-fade mounting medium (Vector Laboratories, CA, USA) for imaging. Image analysis was completed in a masked fashion using four images taken at defined positions and quantified using ImageJ software. 
The analysis was performed in a masked fashion by three separate observers, then averaged. To achieve unbiased results, positive and negative controls were included alongside experimental test and control groups. Fluorescent microscopy was performed by trained masked operators. To address selection bias in immunofluorescence, the entire areas of retinal cross-sections were imaged.

\subsection{Statistics}

All experiments were repeated at least 3 times. All data were assessed using one-way ANOVA. When the results were significant, we determined which means differed from each other using Tukey's multiple-comparisons test. Results are expressed as mean \pm standard error of the mean (SEM). Statistical analysis was performed using GraphPad Prism, with $p<0.05$ considered statistically significant. Only significant comparisons are shown in the figures. All the examiners were blinded to the identities of the samples they were analyzing.

\section{Results}

\subsection{HFD Mice Have Normal Glucose Levels but Are Insulin-Resistant}

We first sought to validate our model by confirming in our cohort that HFD feeding led to similar degrees of body weight gain as reported in the literature [10,35]. Mice on HFD showed increased body weights by 4 weeks of feeding $(p=0.0020)$. This increase was sustained throughout the 12-month observation period (Figure 1A). At 12 months, HFD mice had moderately higher lean mass (difference of $5.580 \pm 1.003 \mathrm{~g}, p<0.0001$ ) and water content (difference of $4.517 \pm 0.876, p=0.0001$ ) but a markedly increased fat mass (difference of $21.15 \pm 2.362, p<0.0001$ ) compared to LFD controls (Figure 1B). Unexpectedly, chronic high-fat feeding did not cause hyperglycemia. Despite feeding mice with a HFD for 12 months, the HbA1c levels were not different between HFD and LFD mice (Figure 1C). At 12 months, there was no difference in fasting blood glucose levels (Figure 1D, basal) and intraperitoneal glucose tolerance test (IP-GTT) did not show any significant differences between LFD and HFD mice (Figure 1D). However, due to the very high levels of insulin in HFD mice $(0.6 \mathrm{ng} / \mathrm{mL}$ for LFD and $3.5 \mathrm{ng} / \mathrm{mL}$ for HFD; Figure 1E, basal), the insulin sensitivity index demonstrated that HFD mice had much lower insulin sensitivity compared to LFD mice (Figure 1E,F). Also, plasma total cholesterol levels were higher in HFD mice compared to LFD (174.4 vs. 114.9, $p=0.0008$ ) (Figure 1G)
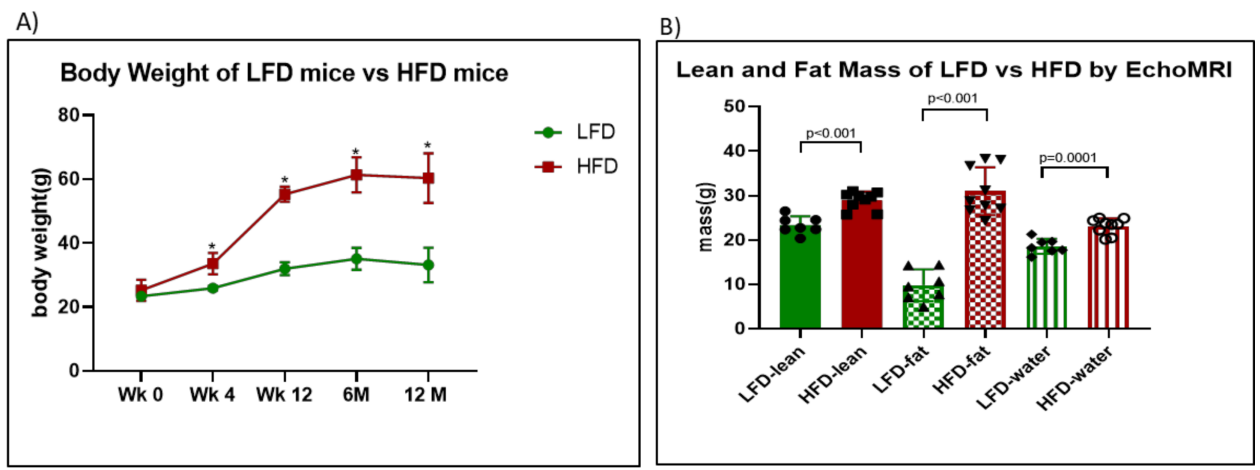

Figure 1. Cont. 

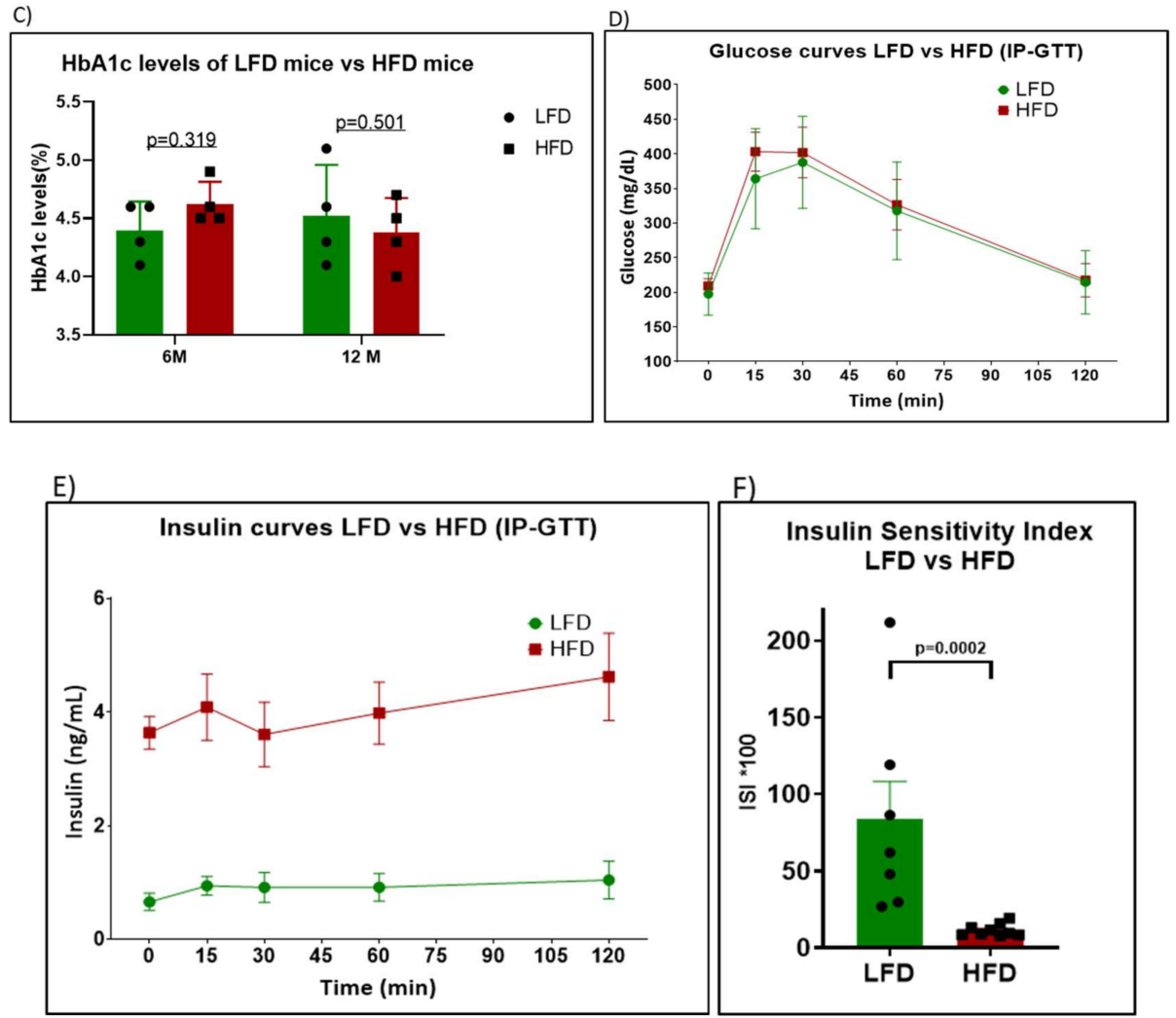

G)

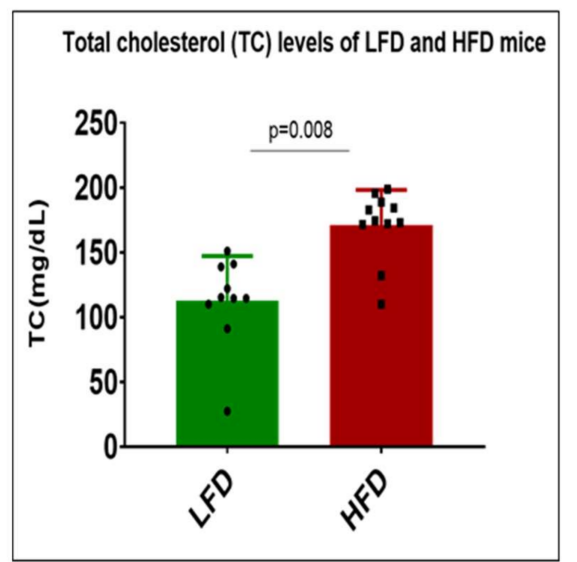

Figure 1. Body weight, glucose levels, and insulin sensitivity of high-fat diet (HFD) mice vs. low-fat diet (LFD) mice. (A) Body weights as measured for mice on LFD (green) and HFD (red) for 12 months. $\left({ }^{*} p<0.000001 ; n=6\right)$. (B) Lean mass, fat mass and water content of LFD mice vs. HFD mice. (C) Glycated hemoglobin (HbA1c) levels measured for the mice after 6 months and 12 months. (D-G) Glucose curves ( $p>0.46$ for all time points), insulin curves ( $p<0.0018$ for all time points), insulin sensitivity index, and total cholesterol levels for LFD mice vs. HFD mice, respectively, following intraperitoneal glucose tolerance test (IP-GTT) after 12 months of feeding.

\subsection{HFD Mice Have Functional Deficits in Their Retinas}

Full-field ERG under both scotopic and photopic conditions was performed at 6 months and 12 months of HFD feeding (Figure 2A-D). HFD mice at 6 months showed significantly reduced aand $b$-wave amplitudes under scotopic conditions $\left(p=0.00125\right.$ and $p=0.000002$ for $0.25 \mathrm{~cd} . \mathrm{s} / \mathrm{m}^{2}$ and $2.5 \mathrm{~cd} . \mathrm{s} / \mathrm{m}^{2}$ stimulus luminance, respectively) but not photopic conditions when compared to LFD mice. After 12 months of feeding of the respective diets, the difference was not significant $(p=0.183$ and 
$p=0.154$ for $0.25 \mathrm{~cd} . \mathrm{s} / \mathrm{m}^{2}$ and $2.5 \mathrm{~cd} . \mathrm{s} / \mathrm{m}^{2}$ stimulus luminance respectively) (Figure 2C,D). Interestingly, when comparing 6 and 12 months of LFD feeding, the mice experienced marked reductions in both the a- and b- waves under both photopic and scotopic conditions at 12 months (Figure 2E,F), but no significant difference was noted in the HFD-fed mice (Figure 2G,H).
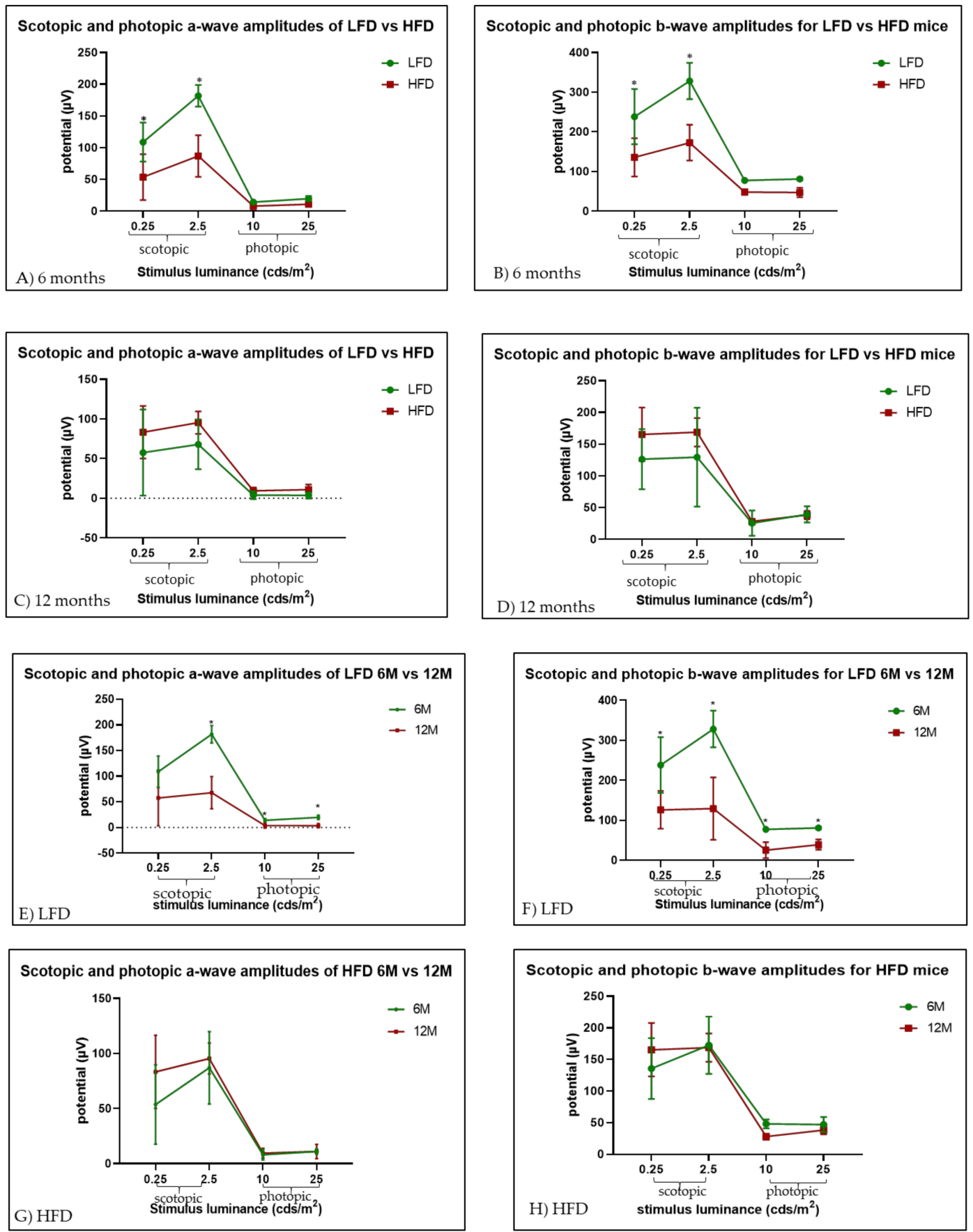

Figure 2. Assessment of retinal function of LFD mice versus HFD mice by electroretinogram (ERG). The amplitudes of a-waves and b-waves were assessed under both scotopic and photopic conditions for LFD mice and HFD mice after 6 months (A,B) and 12 months (C,D). LFD mice showed a significant reduction in retinal response between 6 months and 12 months of feeding $(\mathbf{E}, \mathbf{F})$, but HFD mice did $\operatorname{not}(\mathbf{G}, \mathbf{H}) ;(n=4$ for both groups). 


\subsection{Fundus Photography shows Neural Retinal Lesions in HFD Mice}

In humans, DR is associated with retinal lesions such as hemorrhages, microaneurysms, exudates, and "cotton wool spots" [36]. Fundus photography using Micron IV demonstrated retinal pathology in the HFD mice. Though not statistically significant, HFD mice showed a trend of increased numbers of "lipid-laden-like" lesions (Figure 3A) after 6 months ( $p=0.057)$. However, with 12 months of feeding, HFD mice showed significantly higher number of lesions in the retina (Figure 3B).

\section{A) 6 months}
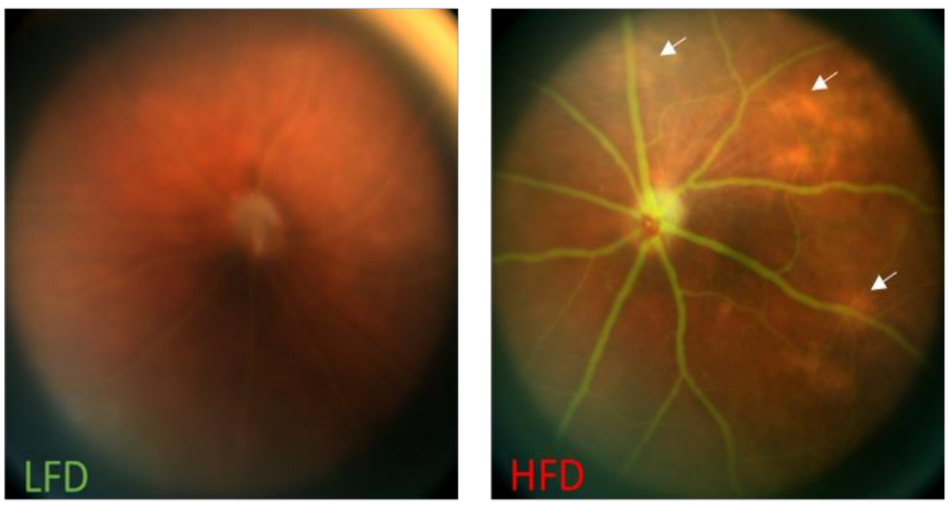

Number of retinal lesions for LFD vs HFD

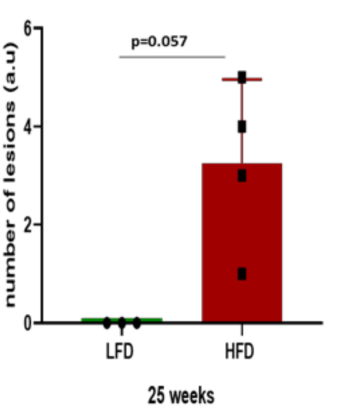

\section{B) 12 months}
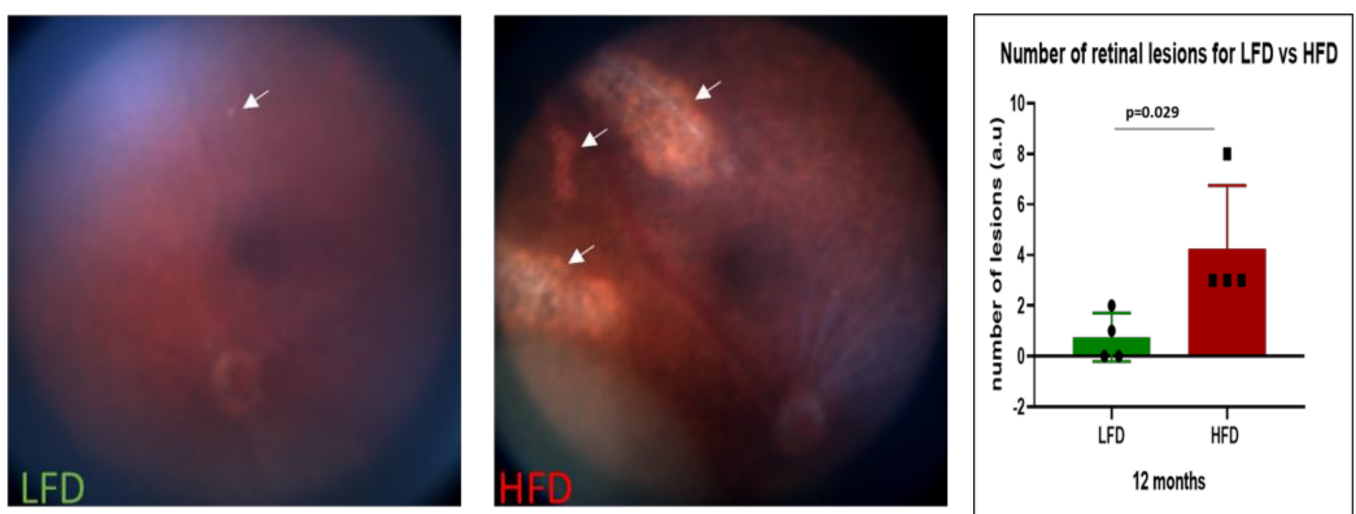

\section{C) 6 months}

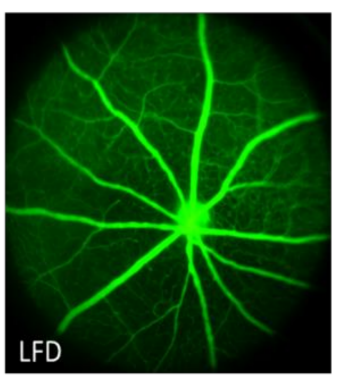

D) 12 months

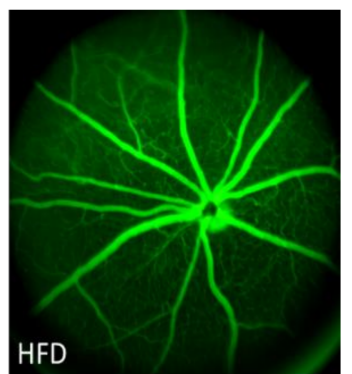

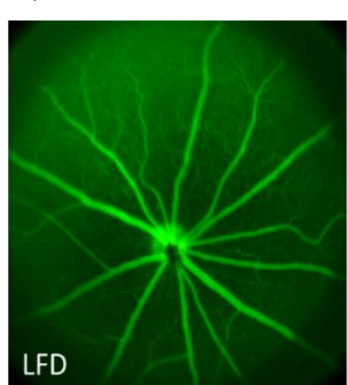

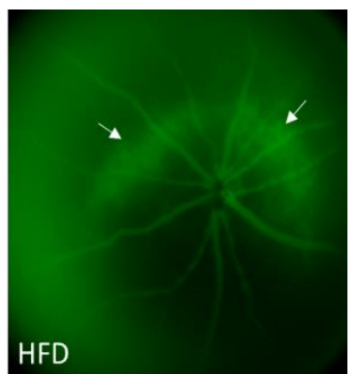

Figure 3. Assessment of retinal lesions by fundus photography $(\mathbf{A}, \mathbf{B})$ and vascular leakage by fluorescein angiography (C,D). HFD mice developed more neural infarcts $((\mathbf{A}, \mathbf{B})$, white arrows) than LFD mice. No infarct was observed for LFD after 6 months (A). However, vascular leakage was observed in HFD mice after 12 months of feeding ((D), white arrows). 


\subsection{Vascular Permeability Changes in HFD Mice}

A hallmark of DR in humans is increased vascular permeability, ultimately leading to diabetic macular edema in humans. To determine if HFD mice developed a breakdown in the blood-retinal barrier, we assessed vascular leakage by fluorescein angiography (FA). At 6 months of HFD feeding, FA did not show any evidence of retinal vascular leakage and were similar to FAs in LFD controls (Figure 3C). However, after 12 months of HFD feeding, increased leakage of fluorescein was observed in the retina compared to LFD control retinas (Figure 3D).

\subsection{Acellular Capillary Formation in HFD Mice}

A well-established feature of diabetic microvascular dysfunction is an increase in the number of acellular capillaries in the retina, defined as basal membrane tubes lacking endothelial cells and pericyte nuclei. At 12 months of HFD feeding, there was no significant increase in acellular capillary numbers in the HFD mice (Figure 4B,C) compared to the LFD mice (Figure 4A,C). However, the HFD retinas showed lower vascular densities compared to LFD retinas (Figure 4D).

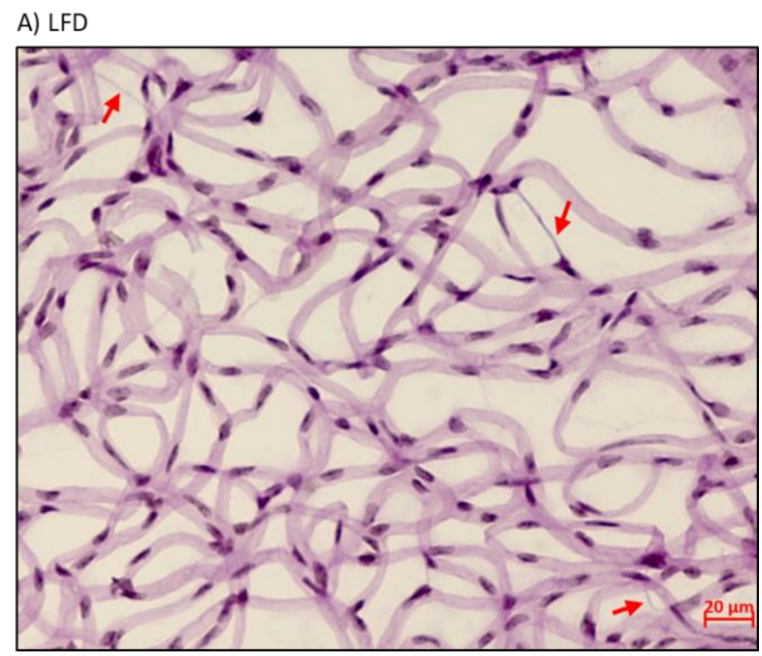

B) HFD

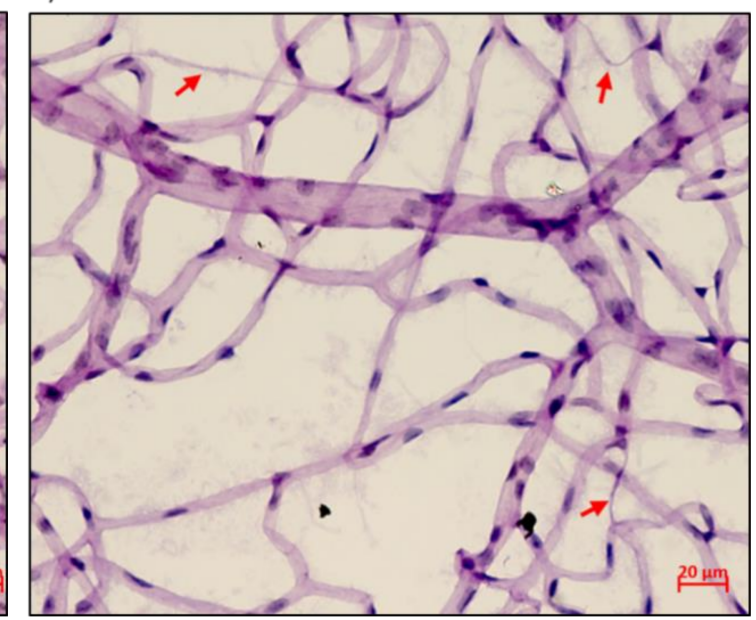

C)

Number of acellular capillaries in the retinas of LFD vs HFD

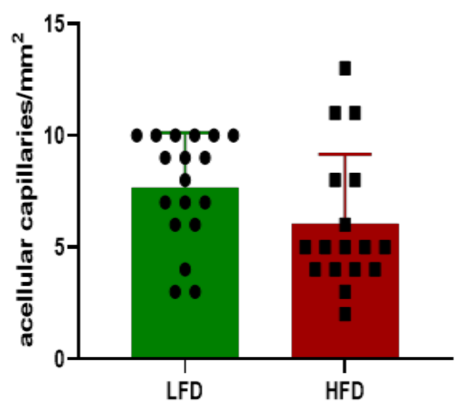

D)

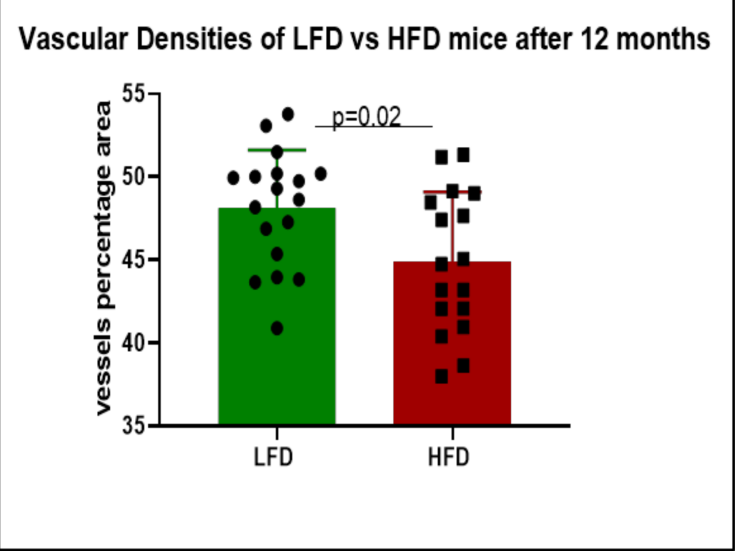

Figure 4. Enumeration of acellular capillaries in LFD and HFD mice after 12 months of feeding. Red arrows indicate acellular capillaries in the retinas of LFD (A) and HFD (B) mice. There was no significant difference in the number of acellular capillaries between both groups $(\mathbf{C})(p=0.086)$. However, HFD retinas showed lesser vascular densities compared to LFD retinas (D). 


\subsection{Retinal Damage, Hypoxia, and Lipid Transport in WD Mice}

While the HFD represents a diet with $60 \%$ fat content that is used as a model of obesity and $\mathrm{T} 2 \mathrm{D}$, the WD with $40 \%$ fat content has garnered popularity as it represents a regimen closer to that actually ingested by humans. Since the WD diet has lower fat content and is not associated with hyperglycemia, we hypothesized that if retinal changes were present they would be subtle compared to those we observed with HFD feeding. To test the validity of our hypothesis, we performed IHC studies and first examined whether there was evidence of glial activation by examining expression of the glial marker GFAP after 6 months of WD feeding. Although there was no statistically significant difference $(p=0.88)$ in the total expression of GFAP between retinas of WD and LFD mice (Figure 5A-C), increased expression of GFAP was observed in selected Vimentin-positive Muller cells in the WD mice (Figure 5G-I) compared to LFD (Figure 5D-F). Increased expression of GFAP in Muller cells is supportive of increased oxidative stress and inflammation in these cells, and suggests that the impact of WD is not experienced uniformly across all Muller cells [37,38].

To assess whether WD feeding induced retinal hypoxia, changes in HIF-1 $\alpha$ expression were examined by IHC. After 6 months of WD feeding, a significant increase $(p=0.025)$ in expression of HIF-1 $\alpha$ was seen in WD mice (Figure 6D) compared to LFD mice (Figure 6C). This was not observed after 3 months of WD feeding (Figure 6A,B). Quantitation of HIF-1 $\alpha$ expression is shown in Figure 6E, demonstrating that WD-fed mice exhibit higher levels than LFD-fed mice. Co-localization with isolectin, a known vascular endothelial cell marker, showed increased expression of HIF- $1 \alpha$ in some endothelial cells in WD mice (I-K) but not in LFD mice (F-H). Higher magnification images from two different WD samples are shown in Figure 6L,M.

Retinal lipid content is regulated in part by liver $X$ receptor beta (LXR $\beta$ ) expression. We next examined changes in LXR $\beta$ expression in the two experimental cohorts. In control mice, LXR $\beta$ localized predominantly in the ganglion cell layer, as well as the inner nuclear layer (Figure 7A), which is the location of the bipolar cells, horizontal cells, and amacrine cells. There was a significant reduction in expression of LXR $\beta$ in WD only in the ganglion cell layer $(p=0.0079)$ after 3 months of feeding (Figure 7B). However, after 6 months of WD feeding, WD mice (Figure 7E) showed significantly reduced expression of LXR $\beta$ in the ganglion cell layer $(p=0.0374)$, inner nuclear layer $(p<0.0001)$, and outer nuclear layer, as well as in the photoreceptors of the outer nuclear layer $(p=0.0020)$. The expression of LXR $\beta$ was reduced after 6 months compared to 3 months of feeding in both LFD $(p<0.0001)$ and WD $(p<0.0001)$ in the nuclear and ganglion cell layers, suggesting an age-related loss in LXR $\beta$.
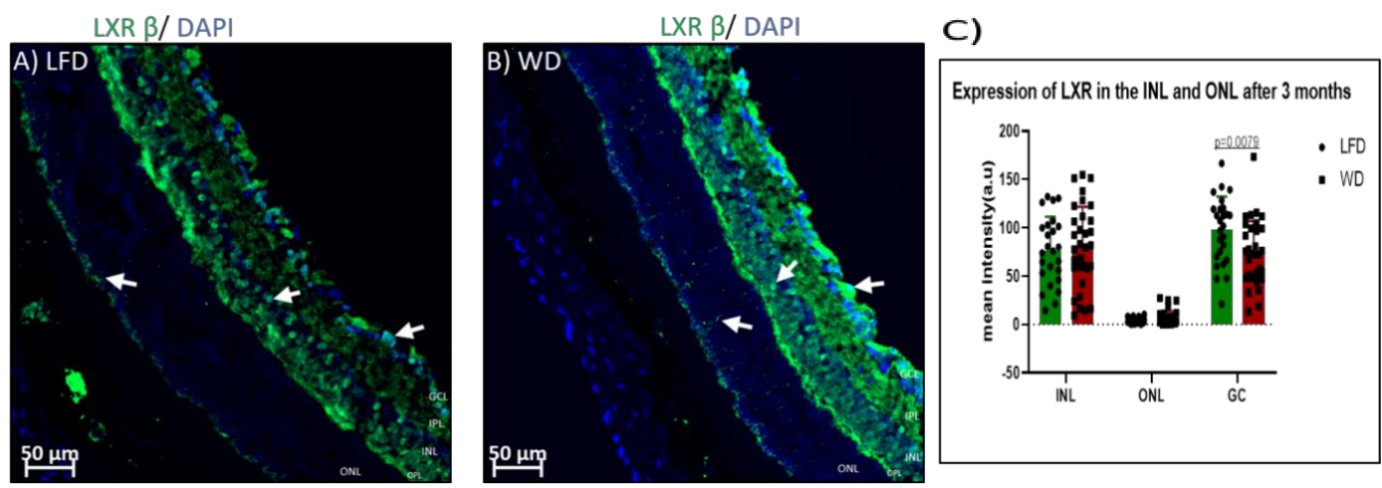

Figure 5. Cont. 
Vimentin / Dapi
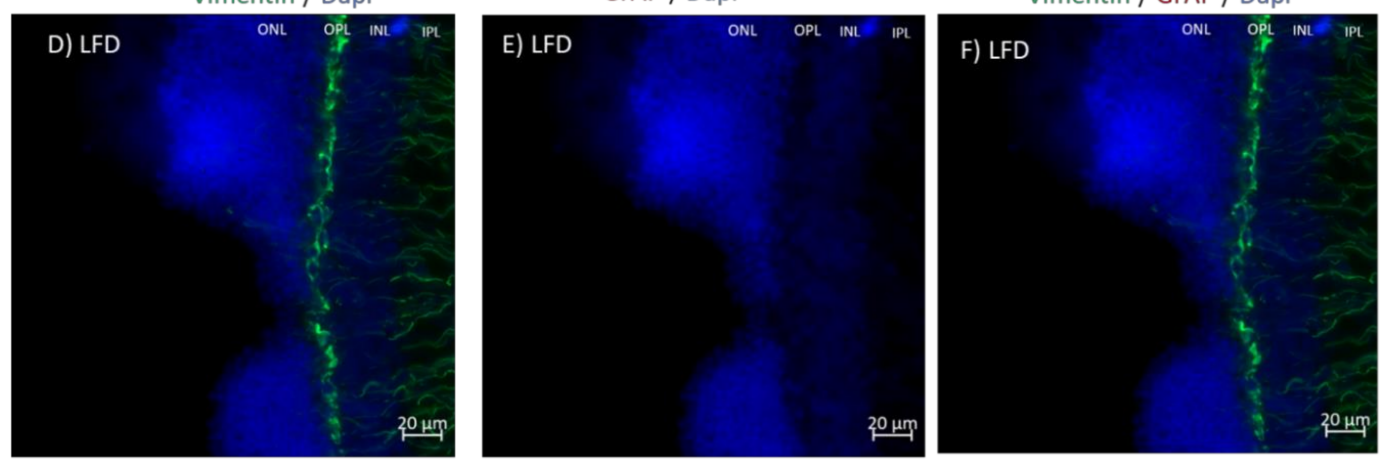

\section{G) WD}
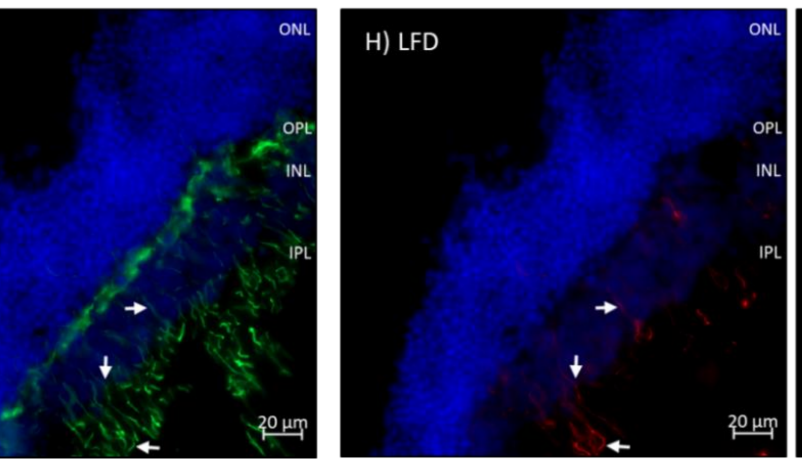

I) LFD

$20 \mu$

Figure 5. Retinal glial fibrillary acidic protein (GFAP) expression after 6 months of feeding. Some Muller cells in Western diet (WD) retinas express GFAP (A,C, white arrows), but not in LFD (A,B), indicating that the impact of WD is not uniform across all Muller cells. Co-localization with Vimentin, a known Mueller cell marker, showed increased expression of GFAP in some Mueller cells in WD mice (G-I) but not in LFD mice (D-F).

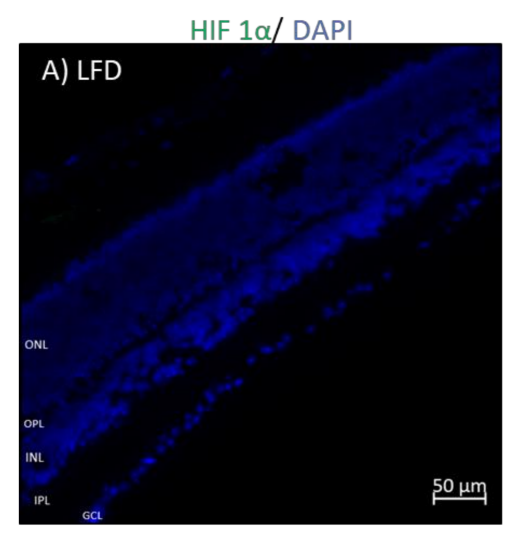

HIF $1 \alpha /$ DAPI

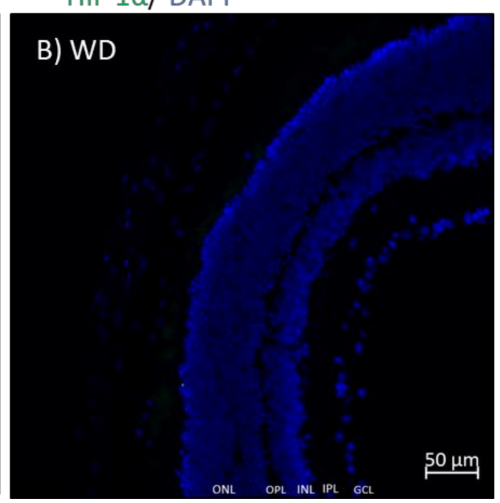

Figure 6. Cont. 

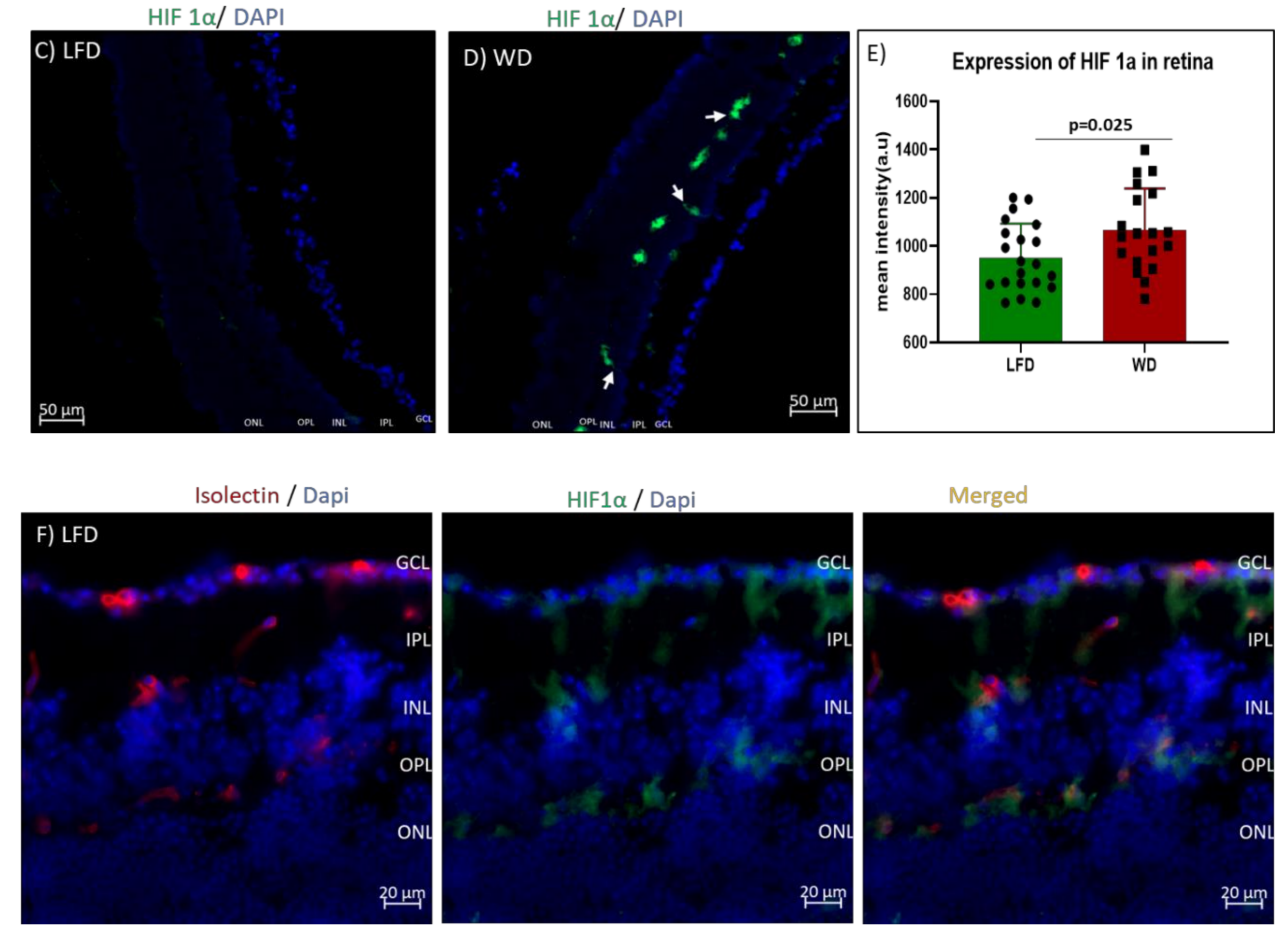

Merged
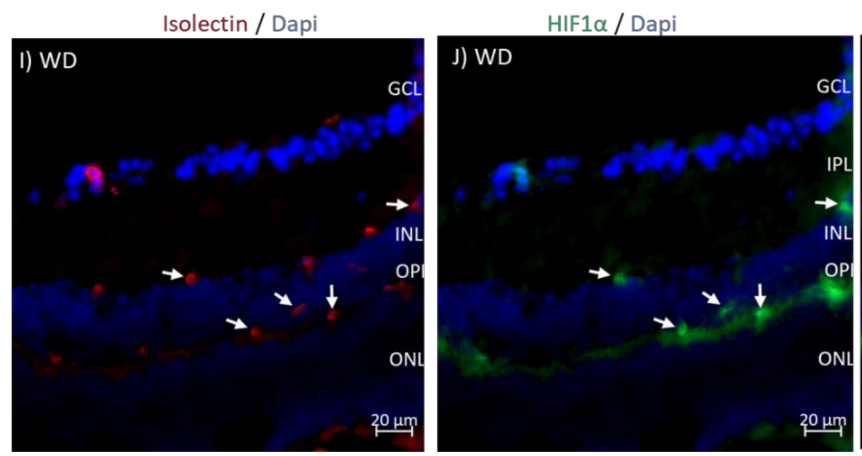

Merged

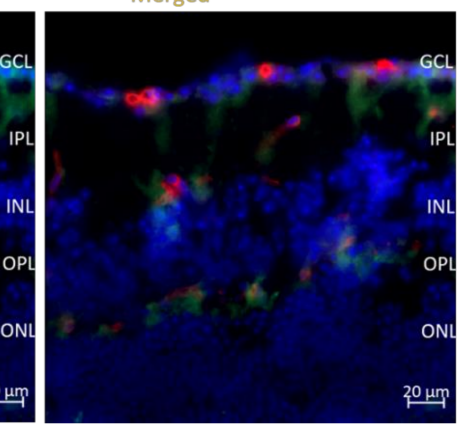

$\mu$
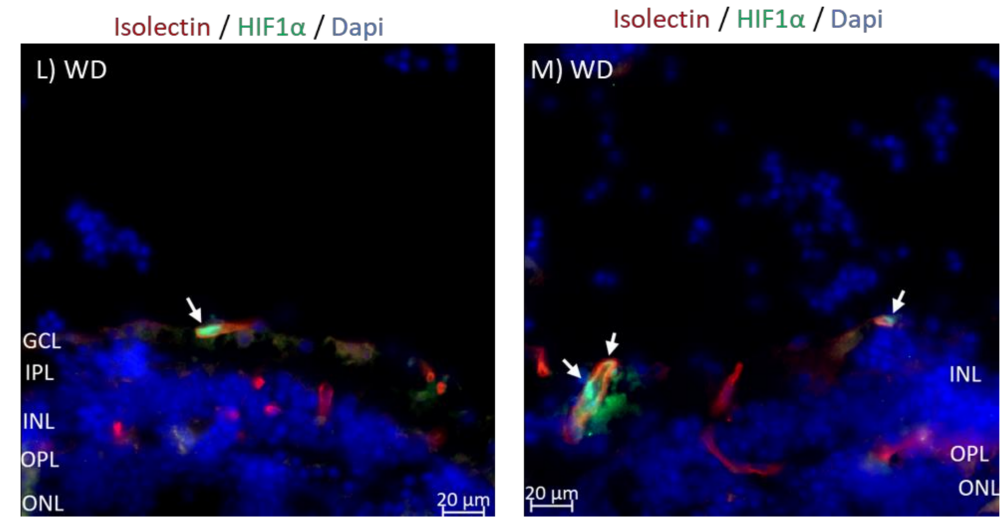

Figure 6. Retinal hypoxia-inducible factor 1 alpha (HIF-1 $\alpha$ ) expression after 3 and 6 months of WD feeding. There was increased expression of HIF-1 $\alpha$ in WD retinas (D, white arrows) compared to LFD retinas $(\mathbf{C})$, as shown by quantification $(\mathbf{E})$. Also, there was no significant difference in expression of HIF-1 $\alpha$ after 3 months of feeding (A,B). Co-localization with isolectin, a known vascular endothelial cell marker, showed increased expression of HIF-1 $\alpha$ in some endothelial cells in WD mice (I-K) but not in LFD mice (F-H). ( $\mathbf{L}, \mathbf{M})$ Magnified merged images from two different WD samples. 
LXR $\beta /$ DAPI
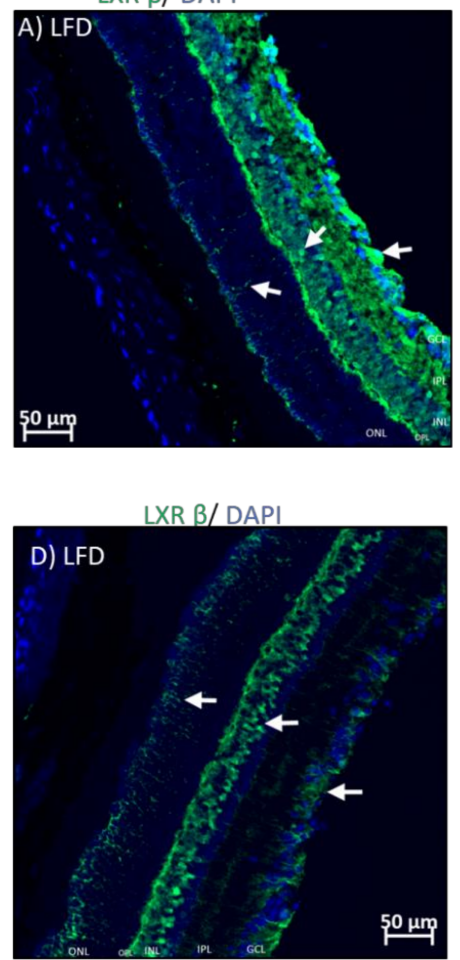

LXR $\beta / D A P I$
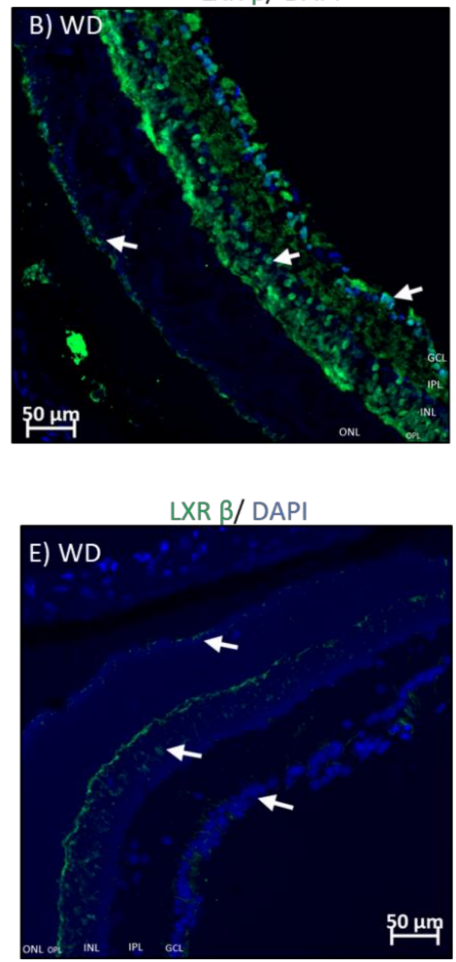

C)
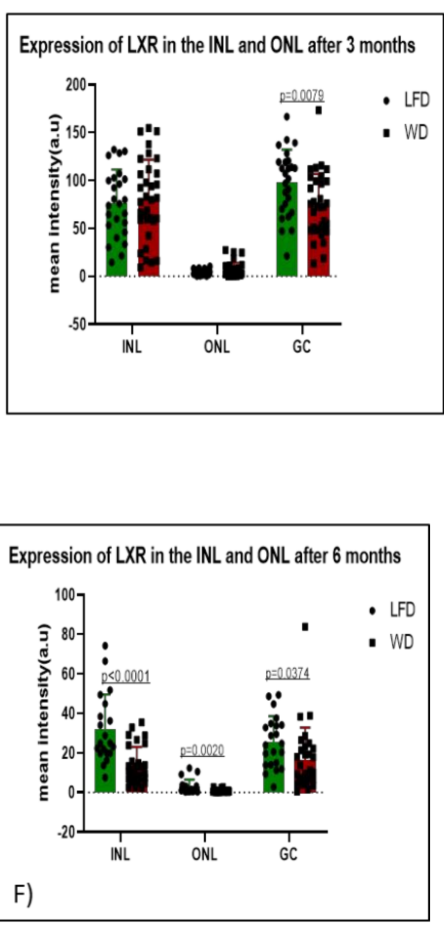

Figure 7. Retinal liver $X$ receptor beta $(L X R \beta)$ expression after 3 and 6 months of feeding. After 3 months of either WD or LFD feeding, there was significant reduction in the expression of LXR $\beta$ in only the ganglion cell layer of WD mice (B) compared to LFD mice (A). However, after 6 months of feeding, there was reduced expression of $\mathrm{LXR} \beta$ in the ganglion cell layer as well as inner and outer nuclear layers of WD mice (E, white arrows) compared to LFD mice (D). Quantification of LXR in the inner nuclear layer (INL) and outer nuclear layer (ONL) at 3 months shows reductions in the ganglion cell (GC) layer (C). At 6 months, reductions are seen in the INL, ONL, and ganglion cell (GC) layer of the WD-fed mice when compared to LFD mice.

\section{Discussion}

Diabetic retinopathy causes both neural and vascular defects, with neural deficits preceding vascular changes [6,39-42]. Even before the onset of clinically detectable retinopathy, diabetic patients have a reduced ERG implicit time [43] and high-frequency flicker amplitude [44]. Later, they experience decreased vascular density [45]. In this study, we have shown that HFD feeding results in a suitable model of prediabetes, with the HFD cohort exhibiting insulin resistance and hypercholesterolemia without hyperglycemia. The retinopathy that is exhibited occurs over a slower time course than in T2D models, where both hyperglycemia and hyperinsulinemia exist.

The HFD mouse has previously been described as a model for T2D [7,46], as C57BL/6J mice fed HFD develop obesity and insulin resistance [47,48], but as we show in this study, this model has a distinct timeline and different characteristics than those seen in T2D. We show that HFD mice have hypercholesterolemia and insulin resistance but the absence of hyperglycemia, which is typical of T2D models.

In agreement with the literature, our study shows that mice fed a HFD have a sustained increase in body weight $[6,49,50]$. As confirmed by EchoMRI, the increase in body weight is primarily due to elevated body fat mass. After 12 weeks of feeding, HFD mice showed a two-fold increase in body fat mass over control LFD mice. Despite the marked increase in fat mass, HFD mice did not develop overt hyperglycemia. Glycated hemoglobin levels measured at 6 months and 12 months showed that both groups had normal glycated hemoglobin, thus indicating a key difference between the HFD model and other T2D rodent models, many of which are genetic. However, HFD mice develop hyperinsulinemia (Figure 1E,F), and their insulin production is sufficient to maintain euglycemia, 
as indicated by their glycated hemoglobin levels. The marked hyperinsulinemia we observed is supported by the literature [6,51-54]. In contrast, T2D in humans is characterized by not only insulin resistance but also the presence of sustained hyperglycemia and elevated $\mathrm{HbA1c}$ levels. When only insulin resistance is present, individuals are described as prediabetics $[55,56]$.

Insulin resistance is believed to play a key role in diabetic neuropathy by increasing oxidative stress and mitochondrial dysfunction [57,58], and may also drive the early neural retinal dysfunction that we observed in our HFD mice. Thus, the HFD mice secrete sufficiently elevated insulin to maintain a normal glucose level, and as such the HFD model may be better characterized as a prediabetes model. Importantly, the incidence of prediabetes is often higher than that of diabetes [59]. The prevalence of prediabetes is also increasing; it is estimated that more than 470 million people worldwide will be suffering from prediabetes by 2030 [60]. Most importantly, the three classical microvascular complications, retinopathy, neuropathy, and nephropathy, have all been documented in individuals with prediabetes [61].

While classifications of diabetes remain "glucose-centric", our study draws attention to the importance of earlier events, when glucose levels are still normal. Thus, in our model, hyperinsulinemia with hypercholesterolemia will likely lead to the retinal pathology observed. Not surprisingly, these pathologies take a longer time to develop than those typically seen when hyperglycemia is also present.

Systemic and retinal lipid abnormalities have been shown to promote retinal damage $[16,62,63]$. Previously, we demonstrated that diabetes-induced disruption of the LXR axis results in abnormal lipid metabolism, inadequate vascular repair, and localized and systemic inflammation [16,64]. The LXRs $(\mathrm{LXR} \alpha$ and $\mathrm{LXR} \beta$ ) play important roles in cholesterol homeostasis [65]. They regulate the expression of reverse cholesterol transporters [12]. Activation of LXRs using pharmacological agents repress inflammatory genes such as TNF- $\alpha$ and IL-1 $\beta$ [66], inhibit the expression of pro-apoptotic factors [67], and prevent the development of DR [12]. We showed that use of GW3965, an LXR agonist, resulted in normalization of cholesterol homeostasis and repression of inflammatory genes, such as iNOS, IL-1 $\beta$, ICAM-1, and CCL2 in the retina [16]. We found that inadequate cholesterol removal due to deficiency in LXR and reduced oxysterol production in the retina due to loss of cytochromes p450 27A1 and 46A1 resulted in widespread retinal pathology [68]. In the current study, we showed that concentrations of $40 \%$ fat in the diet were sufficient to reduce expression of LXR in the inner and outer nuclear layers.

Our study showed that HFD mice develop neural retinal deficits after 6 month of feeding, as both $a-w a v e s$ and b- waves were reduced under scotopic conditions. Unexpectedly, the a- and b- wave responses for LFD mice was significantly less after 12 months compared to the response after 6 months of feeding ( $p<0.01$ for both scotopic and photopic conditions), which suggests that the LFD may have detrimental effects on the neural retina. Because the composition of the diets must be isocaloric, when the amount of fat is reduced, some other dietary component needs to be increased to compensate. Inn the LFD, the amount of sucrose increases from $72 \mathrm{~g}$ to $354 \mathrm{~g}$ and $315 \mathrm{~g}$ of corn starch is also added so that the LFD can be isocaloric with the HFD. However, this largely occurs at the expense of making the diet high in carbohydrates. The literature supports that LFD may be detrimental [69-71]. While we were unable to find literature supporting the impact of LFD specifically on ERGs, the systemic consequences of LFD may indirectly affect the retina, for example by reduced availability of fat-soluble vitamins or changing retinal cholesterol metabolism. Moreover, the increased sucrose and cornstarch in the LFD may have direct deleterious effects [72,73]. LFDs promote insulin resistance, and while most of the research has been performed in humans, these findings may have relevance to murine studies. LFD, typically considered a high carbohydrate diet, is known to promote inflammation [74-76]. A recent study compared ERGs in HFD fed rats, Streptozotocin (STZ) rats and type 2 diabetes (T2D) rats at 6 months to controls. Kowluru found differences between the diabetic ERGs and controls, but no differences between the ERGs of the HFD rats compared to controls; however, Kowluru did not look at 12 month tests and the study was performed in rats, not in mice [77]. Thus, it is difficult to compare these findings with our results.

While neural damage was detected at 6 months, the vascular damage was not observed until much later. This is in agreement with Rajagopal et al. [6], who demonstrated that vascular damage was not 
observed at 6 months of HFD feeding. However, despite the absence of vascular damage after 6 months of HFD, we observed the presence of "lipid-laden like" lesions, and also neural infarcts similar to what is described in humans as "cotton-wool" spots. These lesions, which appeared to increase as the retinopathy progressed in the HFD mice, could become a useful measure of retinal damage and may be sensitive enough to use as a novel endpoint for the preclinical investigation of therapeutic agents.

GFAP is normally expressed in retinal astrocytes in rodents; however, during stress and inflammation, Muller cells [37] respond by increasing GFAP expression. In this study, we show that WD induces GFAP expression in selective Muller cells, supporting the presence of increased stress and inflammation in the retina of these mice. Kim et al. have reported increased inflammation in other tissues such as adipose tissue and intestines [78]. Lee et al. showed increased numbers of activated macrophages in the retina of HFD mice [79]. In both humans and rodents, obesity-induced diabetes is associated with hypoxia in tissues such adipose tissue, and suppression of HIF- $1 \alpha$ mitigates tissue-specific pathological changes associated with HFD [80]. The liver, brain, kidney, and heart display tissue-specific regulation of HIF-1 $\alpha$ under systemic hypoxia [81]. After 6 months, but not after 3 months, we observed that HIF-1 $\alpha$ expression is increased in the WD retinas compared to LFD controls. Similar to our observation in the retina of 3-month-old mice on WD, Prasad et al. showed the absence of pimonidazole staining in the kidneys of 10-11-week old $\mathrm{db} / \mathrm{db}$ mice [82], also indicating the absence of hypoxia response in the kidneys at this time point.

\section{Conclusions}

Our study demonstrates that HFD feeding generates a useful prediabetes model. Specifically, the combination of hypercholesterolemia and insulin resistance are sufficient to induce retinal dysfunction with a slower time course of development compared to T2D models such as the $\mathrm{db} / \mathrm{db}$ mouse. In agreement with reports describing diabetes models, we show that neural functional deficits are the earliest indicator of damage in the retina of this prediabetes model before vascular changes. Key molecular targets such as HIF-1 $\alpha$ and the LXRs provide insights into the retinal pathobiology observed in this hypercholesterolemic, hyperinsulinemic model. The appearance and frequency of neural infarcts or "lipid-laden lesions" in the retina of HFD mice could represent a novel endpoint for evaluation of therapeutic interventions.

Supplementary Materials: The following are available online at http://www.mdpi.com/2073-4409/9/2/464/s1, Table S1: Detailed Composition of high-fat diet (HFD), Western diet (WD), and low-fat diet (LFD).

Author Contributions: Conceptualization, M.L., P.R.N., and M.B.G.; data curation, B.A.-B. and S.K.N.; formal analysis, B.A.-B., S.K.N., B.A.J., and M.B.G.; funding acquisition, M.B.G.; investigation, B.A.-B., S.K.N., S.L.C., B.A., C.P.V., Y.A.-A., M.D., B.A.J., X.X.W., D.C., and M.B.G.; methodology, B.A.-B., S.K.N., P.R.N., and M.B.G.; project administration, P.R.N. and M.B.G.; resources, M.L., P.R.N., and M.B.G.; supervision, M.L. and P.R.N.; validation, B.A.-B. and S.L.C.; visualization, B.A.-B.; writing-original draft, B.A.-B., S.K.N., P.R.N., and M.B.G.; writing-review and editing, B.A.-B., S.K.N., S.L.C., B.A., C.P.V., Y.A.-A., B.A.J., M.L., P.R.N., and M.B.G. All authors have read and agreed to the published version of the manuscript.

Funding: M.G is supported by NIH funding (EY012601, EY028037, and EY028858). P.R.N is supported by NIH funding (HL122505, HL137799); M.L is supported by NIH funding (DK116567). BAJ is supported by the National Center for Advancing Translational Sciences of the NIH under award number TL1TR001431.

Conflicts of Interest: The authors declare no conflict of interest.

\section{References}

1. Cho, N.; Shaw, J.; Karuranga, S.; Huang, Y.; Fernandes, J.D.R.; Ohlrogge, A.; Malanda, B. IDF Diabetes Atlas: Global estimates of diabetes prevalence for 2017 and projections for 2045. Diabetes Res. Clin. Pr. 2018, 138, 271-281. [CrossRef] [PubMed]

2. Chatterjee, S.; Khunti, K.; Davies, M.J. Type 2 diabetes. Lancet 2017, 389, 2239-2251. [CrossRef]

3. Busik, J.V.; Tikhonenko, M.; Bhatwadekar, A.; Opreanu, M.; Yakubova, N.; Caballero, S.; Player, D.; Nakagawa, T.; Afzal, A.; Kielczewski, J.; et al. Diabetic retinopathy is associated with bone marrow neuropathy and a depressed peripheral clock. J. Exp. Med. 2009, 206, 2897-2906. [CrossRef] [PubMed] 
4. Turner, R.C.; Cull, C.A.; Frighi, V.; Holman, R.R.; UK Prospective Diabetes Study (UKPDS) Group. Glycemic Control With Diet Sulfonylurea, Metformin, or Insulin in Patients with Type 2 Diabetes MellitusProgressive Requirement for Multiple Therapies (UKPDS 49). JAMA 1999, 281, 2005. [CrossRef] [PubMed]

5. Yao, Z.; Gu, Y.; Zhang, Q.; Liu, L.; Meng, G.; Wu, H.; Xia, Y.; Bao, X.; Shi, H.; Sun, S. Estimated daily quercetin intake and association with the prevalence of type 2 diabetes mellitus in chinese adults. Eur. J. Nutr. 2019, 58, 819-830. [CrossRef]

6. Rajagopal, R.; Bligard, G.W.; Zhang, S.; Yin, L.; Lukasiewicz, P.; Semenkovich, C.F. Functional Deficits Precede Structural Lesions in Mice With High-Fat Diet-Induced Diabetic Retinopathy. Diabetes 2016, 65, 1072-1084. [CrossRef]

7. Winzell, M.S.; Ahrén, B. The high-fat diet-fed mouse: A model for studying mechanisms and treatment of impaired glucose tolerance and type 2 diabetes. Diabetes 2004, 53, S215-S219. [CrossRef]

8. Liou, C.-J.; Lee, Y.-K.; Ting, N.-C.; Chen, Y.-L.; Shen, S.-C.; Wu, S.-J.; Huang, W.-C. Protective Effects of Licochalcone A Ameliorates Obesity and Non-Alcoholic Fatty Liver Disease Via Promotion of the Sirt-1/AMPK Pathway in Mice Fed a High-Fat Diet. Cells 2019, 8, 447. [CrossRef]

9. Collins, S.; Martin, T.L.; Surwit, R.S.; Robidoux, J. Genetic vulnerability to diet-induced obesity in the C57BL/6J mouse: Physiological and molecular characteristics. Physiol. Behav. 2004, 81, 243-248. [CrossRef]

10. Illesca, P.; Valenzuela, R.; Espinosa, A.; Echeverría, F.; Soto-Alarcon, S.; Ortiz, M.; Videla, L.A. Hydroxytyrosol supplementation ameliorates the metabolic disturbances in white adipose tissue from mice fed a high-fat diet through recovery of transcription factors nrf2, srebp-1c, ppar- $\gamma$ and nf-kb. Biomed. Pharmacother. 2019, 109, 2472-2481. [CrossRef]

11. Declèves, A.-E.; Mathew, A.V.; Armando, A.M.; Han, X.; Dennis, E.A.; Quehenberger, O.; Sharma, K.; Decl\&egraveves, A.-E. AMP-activated protein kinase activation ameliorates eicosanoid dysregulation in high-fat-induced kidney disease in mice. J. Lipid Res. 2019, 60, 937-952. [CrossRef] [PubMed]

12. Hazra, S.; Rasheed, A.; Bhatwadekar, A.; Wang, X.; Shaw, L.C.; Patel, M.; Caballero, S.; Magomedova, L.; Solis, N.; Yan, Y.; et al. Liver X Receptor Modulates Diabetic Retinopathy Outcome in a Mouse Model of Streptozotocin-Induced Diabetes. Diabetes 2012, 61, 3270-3279. [CrossRef]

13. Wang, X.X.; Jiang, T.; Shen, Y.; Caldas, Y.; Miyazaki-Anzai, S.; Santamaria, H.; Urbanek, C.; Solis, N.; Scherzer, P.; Lewis, L.; et al. Diabetic Nephropathy Is Accelerated by Farnesoid X Receptor Deficiency and Inhibited by Farnesoid X Receptor Activation in a Type 1 Diabetes Model. Diabetes 2010, 59, $2916-2927$. [CrossRef] [PubMed]

14. Chen, X.; Yuan, H.; Shi, F.; Zhu, Y. Effect of garden cress in reducing blood glucose, improving blood lipids and reducing oxidative stress in a mouse model of diabetes induced by a high fat diet and streptozotocin. J. Sci. Food Agric. 2019. [CrossRef] [PubMed]

15. Zheng, W.; Mast, N.; Saadane, A.; Pikuleva, I.A. Pathways of cholesterol homeostasis in mouse retina responsive to dietary and pharmacologic treatments. J. Lipid Res. 2015, 56, 81-97. [CrossRef]

16. Hammer, S.S.; Beli, E.; Kady, N.; Wang, Q.; Wood, K.; Lydic, T.A.; Malek, G.; Saban, D.R.; Wang, X.X.; Hazra, S.; et al. The Mechanism of Diabetic Retinopathy Pathogenesis Unifying Key Lipid Regulators, Sirtuin 1 and Liver X Receptor. EBioMedicine 2017, 22, 181-190. [CrossRef]

17. Li, Q.; Zemel, E.; Miller, B.; Perlman, I. Early Retinal Damage in Experimental Diabetes: Electroretinographical and Morphological Observations. Exp. Eye Res. 2002, 74, 615-625. [CrossRef]

18. Krady, J.K.; Basu, A.; Allen, C.M.; Xu, Y.; LaNoue, K.F.; Gardner, T.W.; Levison, S.W. Minocycline reduces proinflammatory cytokine expression, microglial activation, and caspase-3 activation in a rodent model of diabetic retinopathy. Diabetes 2005, 54, 1559-1565. [CrossRef]

19. Dahl, D. The radial glia of Müller in the rat retina and their response to injury. An immunofluorescence study with antibodies to the glial fibrillary acidic (GFA) protein. Exp. Eye Res. 1979, 28, 63-69. [CrossRef]

20. Osborne, N.N.; Block, F.; Sontag, K.-H. Reduction of ocular blood flow results in glial fibrillary acidic protein (GFAP) expression in rat retinal Müller cells. Vis. Neurosci. 1991, 7, 637-639. [CrossRef]

21. Penn, J.S.; Thum, A.L.; Rhem, M.N.; Dell, S.J. Effects of oxygen rearing on the electroretinogram and GFA-protein in the rat. Investig. Ophthalmol. Vis. Sci. 1988, 29, 1623-1630.

22. Tanaka, Y.; Takagi, R.; Ohta, T.; Sasase, T.; Kobayashi, M.; Toyoda, F.; Shimmura, M.; Kinoshita, N.; Takano, H.; Kakehashi, A. Pathological Features of Diabetic Retinopathy in Spontaneously Diabetic Torii Fatty Rats. J. Diabetes Res. 2019, 2019, 8724818. [CrossRef] [PubMed] 
23. Fan, Y.; Lai, J.; Yuan, Y.; Wang, L.; Wang, Q.; Yuan, F. Taurine protects retinal cells and improves synaptic connections in early diabetic rats. Curr. Eye Res. 2020, 45, 52-63. [CrossRef]

24. Bahr, H.I.; Abdelghany, A.A.; Galhom, R.A.; Barakat, B.M.; Arafa, E.-S.A.; Fawzy, M.S. Duloxetine protects against experimental diabetic retinopathy in mice through retinal GFAP downregulation and modulation of neurotrophic factors. Exp. Eye Res. 2019, 186, 107742. [CrossRef]

25. Gu, L.; Xu, H.; Zhang, C.; Yang, Q.; Zhang, L.; Zhang, J. Time-dependent changes in hypoxia-and gliosis-related factors in experimental diabetic retinopathy. Eye 2019, 33, 600. [CrossRef]

26. Chen, J.; Chen, J.; Fu, H.; Li, Y.; Wang, L.; Luo, S.; Lu, H. Hypoxia exacerbates nonalcoholic fatty liver disease via the HIF-2 $\alpha$ /PPAR $\alpha$ pathway. Am. J. Physiol. Metab. 2019, 317, E710-E722. [CrossRef]

27. Han, J.; He, Y.; Zhao, H.; Xu, X. Hypoxia inducible factor-1 promotes liver fibrosis in nonalcoholic fatty liver disease by activating PTEN/p65 signaling pathway. J. Cell. Biochem. 2019, 120, 14735-14744. [CrossRef]

28. Carabelli, J.; Burgueño, A.L.; Rosselli, M.S.; Gianotti, T.F.; Lago, N.R.; Pirola, C.J.; Sookoian, S. High fat diet-induced liver steatosis promotes an increase in liver mitochondrial biogenesis in response to hypoxia. J. Cell. Mol. Med. 2011, 15, 1329-1338. [CrossRef]

29. Beli, E.; Yan, Y.; Moldovan, L.; Vieira, C.P.; Gao, R.; Duan, Y.; Prasad, R.; Bhatwadekar, A.; White, F.A.; Townsend, S.D.; et al. Restructuring of the Gut Microbiome by Intermittent Fasting Prevents Retinopathy and Prolongs Survival in db/db Mice. Diabetes 2018, 67, 1867-1879. [CrossRef]

30. Li, M.; Reynolds, C.M.; Gray, C.; Patel, R.; Sloboda, D.M.; Vickers, M.H. Long-term effects of a maternal high-fat: High-fructose diet on offspring growth and metabolism and impact of maternal taurine supplementation. J. Dev. Orig. Heal. Dis. 2019, 1-8. [CrossRef]

31. Matsuda, M.; DeFronzo, R.A. Insulin sensitivity indices obtained from oral glucose tolerance testing: Comparison with the euglycemic insulin clamp. Diabetes Care 1999, 22, 1462-1470. [CrossRef]

32. Veenstra, A.; Liu, H.; Lee, C.A.; Du, Y.; Tang, J.; Kern, T.S. Diabetic Retinopathy: Retina-Specific Methods for Maintenance of Diabetic Rodents and Evaluation of Vascular Histopathology and Molecular Abnormalities. Curr. Protoc. Mouse Boil. 2015, 5, 247-270. [CrossRef]

33. Bhatwadekar, A.D.; Duan, Y.; Chakravarthy, H.; Korah, M.; Caballero, S.; Busik, J.V.; Grant, M.B. Ataxia telangiectasia mutated dysregulation results in diabetic retinopathy. Stem Cells 2016, 34, 405-417. [CrossRef]

34. Léger, H.; Santana, E.; Beltran, A.W.; Luca, F.C. Preparation of Mouse Retinal Cryo-sections for Immunohistochemistry. J. Vis. Exp. 2019, e59683. [CrossRef]

35. Fan, S.; Zhang, Y.; Hu, N.; Sun, Q.; Ding, X.; Li, G.; Zheng, B.; Gu, M.; Huang, F.; Sun, Y.-Q.; et al. Extract of Kuding Tea Prevents High-Fat Diet-Induced Metabolic Disorders in C57BL/6 Mice via Liver X Receptor (LXR) $\beta$ Antagonism. PLoS ONE 2012, 7, e51007. [CrossRef]

36. Engerman, R.L. Pathogenesis of diabetic retinopathy. Diabetes 1989, 38, 1203-1206. [CrossRef]

37. Kumar, B.; Gupta, S.K.; Nag, T.C.; Srivastava, S.; Saxena, R.; Jha, K.A.; Srinivasan, B.P. Retinal neuroprotective effects of quercetin in streptozotocin-induced diabetic rats. Exp. Eye Res. 2014, 125, 193-202. [CrossRef]

38. Eisenfeld, A.J.; Bunt-Milam, A.H.; Sarthy, P.V. Müller cell expression of glial fibrillary acidic protein after genetic and experimental photoreceptor degeneration in the rat retina. Investig. Ophthalmol. Vis. Sci. 1984, $25,1321-1328$.

39. Lieth, E.; Gardner, T.W.; Barber, A.J.; Antonetti, D.A. Retinal neurodegeneration: Early pathology in diabetes. Clin. Exp. Ophthalmol. Viewpoint 2000, 28, 3-8. [CrossRef]

40. Barber, A.J. A new view of diabetic retinopathy: A neurodegenerative disease of the eye. Prog. Neuro-Psychopharmacol. Biol. Psychiatry 2003, 27, 283-290. [CrossRef]

41. Stratton, I.M.; Kohner, E.M.; Aldington, S.J.; Turner, R.C.; Holman, R.R.; Manley, S.E.; Matthews, D.R.; UKPDS Group UKPDS 50. Risk factors for incidence and progression of retinopathy in Type II diabetes over 6 years from diagnosis. Diabetologia 2001, 44, 156-163. [CrossRef]

42. Tang, J.; Kern, T.S. Inflammation in diabetic retinopathy. Prog. Retin. Eye Res. 2011, 30, 343-358. [CrossRef]

43. Fortune, B.; Schneck, E.M.; Adams, A.J. Multifocal electroretinogram delays reveal local retinal dysfunction in early diabetic retinopathy. Investig. Ophthalmol. Vis. Sci. 1999, 40, 2638-2651.

44. McAnany, J.J.; Park, J.C.; Chau, F.Y.; Leiderman, Y.I.; Lim, J.I.; Blair, N.P. Amplitude loss of the high-frequency flicker electroretinogram in early diabetic retinopathy. Retin. 2019, 39, 2032-2039. [CrossRef] [PubMed]

45. Zeng, Y.; Cao, D.; Yu, H.; Yang, D.; Zhuang, X.; Hu, Y.; Li, J.; Yang, J.; Wu, Q.; Liu, B.; et al. Early retinal neurovascular impairment in patients with diabetes without clinically detectable retinopathy. Br. J. Ophthalmol. 2019, 103, 1747-1752. [PubMed] 
46. Sone, H.; Kagawa, Y. Pancreatic beta cell senescence contributes to the pathogenesis of type 2 diabetes in high-fat diet-induced diabetic mice. Diabetologia 2005, 48, 58-67. [CrossRef]

47. Surwit, R.S.; Kuhn, C.M.; Cochrane, C.; McCubbin, A.J.; Feinglos, M.N. Diet-induced type II diabetes in C57BL/6J mice. Diabetes 1988, 37, 1163-1167. [CrossRef]

48. Surwit, R.S.; Feinglos, M.N.; Rodin, J.; Sutherland, A.; Petro, E.A.; Opara, E.C.; Kuhn, C.M.; Rebuffé-Scrive, M. Differential effects of fat and sucrose on the development of obesity and diabetes in C57BL/6J and A/J mice. Metabolism 1995, 44, 645-651. [CrossRef]

49. Cani, P.D.; Neyrinck, A.M.; Fava, F.; Knauf, C.; Burcelin, R.G.; Tuohy, K.M.; Gibson, G.R.; Delzenne, N.M. Selective increases of bifidobacteria in gut microflora improve high-fat-diet-induced diabetes in mice through a mechanism associated with endotoxaemia. Diabetologia 2007, 50, 2374-2383. [CrossRef]

50. Lin, S.; Thomas, T.; Storlien, L.; Huang, X. Development of high fat diet-induced obesity and leptin resistance in C57Bl/6J mice. Int. J. Obes. 2000, 24, 639-646. [CrossRef]

51. Membrez, M.; Blancher, F.; Jaquet, M.; Bibiloni, R.; Cani, P.D.; Burcelin, R.G.; Corthesy, I.; Chou, C.J.; Macé, K. Gut microbiota modulation with norfloxacin and ampicillin enhances glucose tolerance in mice. FASEB J. 2008, 22, 2416-2426. [CrossRef] [PubMed]

52. Rabot, S.; Membrez, M.; Bruneau, A.; Gerard, P.; Harach, T.; Moser, M.; Raymond, F.; Mansourian, R.; Chou, C.J. Germ-free C57BL/6J mice are resistant to high-fat-diet-induced insulin resistance and have altered cholesterol metabolism. FASEB J. 2010, 24, 4948-4959. [CrossRef] [PubMed]

53. Uysal, K.T.; Wiesbrock, S.M.; Marino, M.W.; Hotamisligil, G.S. Protection from obesity-induced insulin resistance in mice lacking TNF- $\alpha$ function. Nature 1997, 389, 610-614. [CrossRef] [PubMed]

54. Elchebly, M. Increased Insulin Sensitivity and Obesity Resistance in Mice Lacking the Protein Tyrosine Phosphatase-1B Gene. Sci. 1999, 283, 1544-1548. [CrossRef]

55. Nathan, D.M.; Buse, J.B.; Davidson, M.B.; Ferrannini, E.; Holman, R.R.; Sherwin, R.; Zinman, B. Medical management of hyperglycemia in type 2 diabetes: A consensus algorithm for the initiation and adjustment of therapy: A consensus statement of the American Diabetes Association and the European Association for the Study of Diabetes. Diabetes Care 2009, 32, 193-203. [CrossRef] [PubMed]

56. Kim, K.; Kim, E.S.; Yu, S.-Y. Longitudinal Relationship Between Retinal Diabetic Neurodegeneration and Progression of Diabetic Retinopathy in Patients With Type 2 Diabetes. Am. J. Ophthalmol. 2018, 196, 165-172. [CrossRef]

57. Kim, B.; McLean, L.L.; Philip, S.S.; Feldman, E.L. Hyperinsulinemia induces insulin resistance in dorsal root ganglion neurons. Endocrinology 2011, 152, 3638-3647. [CrossRef]

58. Kim, B.; Feldman, E.L. Insulin resistance in the nervous system. Trends Endocrinol. Metab. 2012, $23,133-141$. [CrossRef]

59. Das, A.K.; Kalra, S.; Tiwaskar, M.; Bajaj, S.; Seshadri, K.; Chowdhury, S.; Sahay, R.; Indurkar, S.; Unnikrishnan, A.G.; Phadke, U.; et al. Expert Group Consensus Opinion: Role of Anti-inflammatory Agents in the Management of Type-2 Diabetes (T2D). J. Assoc. Physicians India 2019, 67, 65-74.

60. Tabák, A.G.; Herder, C.; Rathmann, W.; Brunner, E.J.; Kivimäki, M. Prediabetes: A high-risk state for diabetes development. Lancet 2012, 379, 2279-2290. [CrossRef]

61. Lamparter, J.; Raum, P.; Pfeiffer, N.; Peto, T.; Höhn, R.; Elflein, H.; Wild, P.; Schulz, A.; Schneider, A.; Mirshahi, A. Prevalence and associations of diabetic retinopathy in a large cohort of prediabetic subjects: The Gutenberg Health Study. J. Diabetes its Complicat. 2014, 28, 482-487. [CrossRef]

62. Tikhonenko, M.; Lydic, T.A.; Opreanu, M.; Calzi, S.L.; Bozack, S.; McSorley, K.M.; Sochacki, A.L.; Faber, M.S.; Hazra, S.; Duclos, S.; et al. N-3 Polyunsaturated Fatty Acids Prevent Diabetic Retinopathy by Inhibition of Retinal Vascular Damage and Enhanced Endothelial Progenitor Cell Reparative Function. PLoS ONE 2013, 8, e55177. [CrossRef] [PubMed]

63. Busik, J.V.; Esselman, W.J.; Reid, E.G. Examining the role of lipid mediators in diabetic retinopathy. Clin. Lipidol. 2012, 7, 661-675. [CrossRef] [PubMed]

64. Hammer, S.S.; Busik, J.V. The role of dyslipidemia in diabetic retinopathy. Vis. Res. 2017, 139, $228-236$. [CrossRef] [PubMed]

65. Calkin, A.C.; Tontonoz, P. Liver x receptor signaling pathways and atherosclerosis. Arter. Thromb. Vasc. Boil. 2010, 30, 1513-1518. [CrossRef] [PubMed]

66. Zelcer, N.; Tontonoz, P. Liver $\mathrm{X}$ receptors as integrators of metabolic and inflammatory signaling. J. Clin. Investig. 2006, 116, 607-614. [CrossRef] 
67. Steffensen, K.R.; Jakobsson, T.; Gustafsson, J.-Å. Targeting liver X receptors in inflammation. Expert Opin. Ther. Targets 2013, 17, 977-990. [CrossRef]

68. Saadane, A.; Mast, N.; Trichonas, G.; Chakraborty, D.; Hammer, S.; Busik, J.V.; Grant, M.B.; Pikuleva, I.A. Retinal Vascular Abnormalities and Microglia Activation in Mice with Deficiency in Cytochrome P450 46A1-Mediated Cholesterol Removal. Am. J. Pathol. 2019, 189, 405-425. [CrossRef]

69. Sacks, F.M.; Lichtenstein, A.H.; Wu, J.H.; Appel, L.J.; Creager, M.A.; Kris-Etherton, P.M.; Miller, M.; Rimm, E.B.; Rudel, L.L.; Robinson, J.G.; et al. Dietary Fats and Cardiovascular Disease: A Presidential Advisory from the American Heart Association. Circulation 2017, 136, e1-e23. [CrossRef]

70. Andraski, A.B.; Singh, S.A.; Lee, L.H.; Higashi, H.; Smith, N.; Zhang, B.; Aikawa, M.; Sacks, F.M. Effects of Replacing Dietary Monounsaturated Fat With Carbohydrate on HDL (High-Density Lipoprotein) Protein Metabolism and Proteome Composition in Humans. Arter. Thromb. Vasc. Boil. 2019, 39, 2411-2430. [CrossRef]

71. Bolla, A.M.; Caretto, A.; Laurenzi, A.; Scavini, M.; Piemonti, L. Low-Carb and Ketogenic Diets in Type 1 and Type 2 Diabetes. Nutrients 2019, 11, 962. [CrossRef] [PubMed]

72. Gomes, J.A.; Silva, J.F.; Silva, G.C.; Gomes, G.F.; de Oliveira, A.C.; Soares, V.L.; Oliveira, M.C.; Ferreira, A.V.; Aguiar, D.C. High-refined carbohydrate diet consumption induces neuroinflammation and anxiety-like behavior in mice. J. Nutr. Biochem. 2019, 77, 108317. [CrossRef] [PubMed]

73. Tobias, D.K.; Chen, M.; Manson, J.E.; Ludwig, D.S.; Willett, W.; Hu, F.B. Effect of low-fat diet interventions versus other diet interventions on long-term weight change in adults: A systematic review and meta-analysis. Lancet Diabetes Endocrinol. 2015, 3, 968-979. [CrossRef]

74. Vega-López, S.; Venn, B.J.; Slavin, J.L. Relevance of the Glycemic Index and Glycemic Load for Body Weight, Diabetes, and Cardiovascular Disease. Nutrients 2018, 10, 1361. [CrossRef] [PubMed]

75. Livesey, G.; Taylor, R.; Livesey, H.F.; Buyken, A.E.; Jenkins, D.J.A.; Augustin, L.S.A.; Sievenpiper, J.L.; Barclay, A.W.; Liu, S.; Wolever, T.M.S.; et al. Dietary Glycemic Index and Load and the Risk of Type 2 Diabetes: Assessment of Causal Relations. Nutrients 2019, 11, 1436. [CrossRef]

76. Myette-Côté, É.; Durrer, C.; Neudorf, H.; Bammert, T.D.; Botezelli, J.D.; Johnson, J.D.; DeSouza, C.A.; Little, J.P. The effect of a short-term low-carbohydrate, high-fat diet with or without postmeal walks on glycemic control and inflammation in type 2 diabetes: A randomized trial. Am. J. Physiol. Integr. Comp. Physiol. 2018, 315, R1210-R1219.

77. Kowluru, R.A. Retinopathy in a Diet-Induced Type 2 Diabetic Rat Model, and Role of Epigenetic Modifications. Diabetes 2020, db191009. [CrossRef]

78. Kim, K.-A.; Gu, W.; Lee, I.-A.; Joh, E.-H.; Kim, N.-H. High Fat Diet-Induced Gut Microbiota Exacerbates Inflammation and Obesity in Mice via the TLR4 Signaling Pathway. PLoS ONE 2012, 7, e47713. [CrossRef]

79. Lee, J.-J.; Wang, P.-W.; Yang, I.-H.; Huang, H.-M.; Chang, C.-S.; Wu, C.-L.; Chuang, J.-H. High-Fat Diet Induces Toll-Like Receptor 4-Dependent Macrophage/Microglial Cell Activation and Retinal Impairment. Investig. Opthalmol. Vis. Sci. 2015, 56, 3041. [CrossRef]

80. Krishnan, J.; Danzer, C.; Simka, T.; Ukropec, J.; Walter, K.M.; Kumpf, S.; Mirtschink, P.; Ukropcova, B.; Gasperikova, D.; Pedrazzini, T. Dietary obesity-associated hif1 $\alpha$ activation in adipocytes restricts fatty acid oxidation and energy expenditure via suppression of the sirt2-nad+ system. Genes Dev. 2012, 26, 259-270. [CrossRef]

81. Stroka, D.M.; Burkhardt, T.; Desbaillets, I.; Wenger, R.H.; Neil, D.A.; Bauer, C.; Gassmann, M.; Candinas, D. Hif-1 is expressed in normoxic tissue and displays an organ-specific regulation under systemic hypoxia. FASEB J. 2001, 15, 2445-2453. [CrossRef] [PubMed]

82. Prasad, P.; Li, L.-P.; Halter, S.; Cabray, J.; Ye, M.; Batlle, D. Evaluation of renal hypoxia in diabetic mice by BOLD MRI. Investig. Radiol. 2010, 45, 819-822. [CrossRef] [PubMed]

(C) 2020 by the authors. Licensee MDPI, Basel, Switzerland. This article is an open access article distributed under the terms and conditions of the Creative Commons Attribution (CC BY) license (http://creativecommons.org/licenses/by/4.0/). 